This file was dowloaded from the institutional repository Brage NIH - brage.bibsys.no/nih

Gjevestad, G. O., Ottestad, I., Biong, A. S., Iversen, P. O., Retterstøl, K., Raastad, T. ... Holven, K. B. (2017). Consumption of protein-enriched milk has minor effects on inflammation in older adults?: A 12-week double-blind randomized controlled trial. Mechanisms of Ageing and Development, 162, 1-8.

Dette er akseptert versjon av artikkelen, og den kan inneholde små forskjeller fra forlagets pdf-versjon. Forlagets pdf-versjon finner du på sciencedirect.com: http://dx.doi.org/10.1016/j.mad.2017.01.011

This is the acceptec version of the article, and it may contain minor differences from the journal's pdf version. The original publication is available at sciencedirect.com: http://dx.doi.org/10.1016/j.mad.2017.01.011 


\section{Consumption of protein-enriched milk has minor effects on inflammation in older adults - a 12-week double-blind randomized controlled trial}

Gyrd O. Gjevestad ${ }^{1,2}$, Inger Ottestad ${ }^{1}$, Anne Sofie Biong ${ }^{2}$, Per Ole Iversen ${ }^{1,3}$, Kjetil Retterstøl, ${ }^{1,4}$, Truls Raastad $^{5}$, Bjørn S. Skålhegg ${ }^{1}$, Stine M. Ulven ${ }^{1}$ and Kirsten B. Holven ${ }^{1,6}$

${ }^{1}$ Department of Nutrition, Institute of Basic Medical Sciences, P.O. Box 1046, Blindern, 0317 University of Oslo, Norway

${ }^{2}$ TINE SA, Centre for Research and Development, P.O. Box 7, Kalbakken, 0902 Oslo, Norway

${ }^{3}$ Department of Hematology, Oslo University Hospital, P.O. Box 4950 Nydalen, 0424 Oslo, Norway

${ }^{4}$ Lipid Clinic, Oslo University Hospital, P.O. Box 4950 Nydalen, 0424 Oslo, Norway

${ }^{5}$ Department of Physical Performance, Norwegian School of Sport Sciences, P.B. 4104 U.S., 0806 Oslo, Norway

${ }^{6}$ National Advisory Unit on Familial Hypercholesterolemia, Department of Endocrinology, Morbid Obesity and Preventive Medicine, Oslo University Hospital, P.O. Box 4950 Nydalen, 0424 Oslo, Norway.

E-mail addresses:

Gyrd Omholt Gjevestad; g.o.gjevestad@ medisin.uio.no,

Inger Ottestad; inger.ottestad@ medisin.uio.no,

Anne Sofie Biong; anne.sofie.biong@tine.no,

Per Ole Iversen; poiversen@ hotmail.com

Kjetil Retterstøl; kjetil.retterstol@ medisin.uio.no

Truls Raastad; truls.raastad@nih.no

Bjørn S. Skålhegg; b.s.skalhegg@medisin.uio.no

Stine Ulven; smulven@medisin.uio.no, 
Kirsten Bjørklund Holven; k.b.holven@ medisin.uio.no

Corresponding author; Kirsten B. Holven, Department of Nutrition, Institute of Basic Medical Sciences, P.O. Box 1046, Blindern, 0317 University of Oslo, Norway.

A list of authors' last name, as they should appear for PubMed indexing: Gjevestad, Ottestad, Biong, Iversen, Retterstøl, Raastad, Ulven, Holven

Number of figures to print: 2

Number of tables to print: 6 


\section{Highlights}

- The consumption of a low-fat, protein-enriched milk had minor effects on inflammatory related markers after 12 weeks of intervention in older subjects compared to an isocaloric intake of carbohydrate.

- Significant differences between study groups were observed in the mRNA expression levels of NRIH3 and INFG.

- The mRNA level of TNFRSF1A was significantly reduced, while the mRNA level of DPP4 was significantly increased in the control group, with no differences between groups.

- The serum level of sTNFRSF1A increased significantly in both groups after the intervention, while the serum level of TNF $\alpha$ increased significantly in the control group only. No differences were observed between groups. 


\begin{abstract}
Introduction: Aging is associated with increased levels of circulating inflammatory markers and reduced muscle mass and strength.

Objective: We investigated whether intake of protein-enriched milk for 12 weeks would influence markers of inflammation among adults $\geq 70$ years of age with reduced physical strength.

Methods: In a double-blind randomized controlled intervention study, subjects were randomly allocated into two groups, receiving a protein-enriched milk ( 2 x $20 \mathrm{~g}$ protein/d, $\mathrm{n}=14$, mean $( \pm \mathrm{SD})$ age $76.9 \pm 4.9 \mathrm{yrs})$ or an isocaloric carbohydrate drink $(\mathrm{n}=17$, age $77.7 \pm$ $4.8 \mathrm{yrs}$ ) for 12 weeks. We measured serum and mRNA expression levels of inflammatory markers in PBMCs.
\end{abstract}

Results: Significant differences in the mRNA expression of nuclear receptor subfamily, group $H$, member 3 (NR1H3, encoding the LXR $\alpha$ transcription factor) and interferon gamma (INFG) were observed between groups. The mRNA level of TNFRSF1A was significantly reduced, while the mRNA level of dipeptidyl-peptidase 4 (DPP4) was significantly increased, in the control group. The serum level of TNFa increased significantly in the control group, while sTNFRSF1A increased significantly in both groups, but with no significant differences between groups.

Conclusion: Consumption of a low-fat, protein-enriched milk for 12 weeks had minor effects on inflammatory related markers in older adults compared to an isocaloric carbohydrate drink.

Key words: milk protein, older adults, high-protein, inflammation, peripheral blood mononuclear cells, mRNA. 


\section{Highlights}

- The consumption of a low-fat, protein-enriched milk had minor effects on inflammatory related markers after 12 weeks of intervention in older subjects compared to an isocaloric intake of carbohydrate.

- Significant differences between study groups were observed in the mRNA expression levels of NRIH3 (the gene encoding $L X R \alpha$ ) and INFG.

- The mRNA level of TNFRSF1A was significantly reduced, while the mRNA level of DPP4 was significantly increased in the control group, with no differences between groups.

- The serum level of sTNFRSF1A increased significantly in both groups after the intervention, while the serum level of TNF $\alpha$ increased significantly in the control group only. No differences were observed between groups. 


\section{Abbreviations list}

B2M, beta-2-microglobulin; BMI, body mass index; CCL, chemokine (C-C motif) ligand; cDNA, complimentary deoxyribonucleic acid; CXCL16, chemokine (C-X-C motif) ligand 16; DPP4, dipeptidyl-peptidase 4; DXA, dual energy X-ray absorptiometry; g, gravity; Gadd45, growth arrest and DNA-damage-inducible, alpha; hs-CRP, high sensitive C-reactive protein; IFNG, interferon gamma; IGF1, insulin-like growth factor 1; IL, interleukin; IL1RN/IL1Ra, interleukin 1 receptor antagonist; liver X receptor alpha, LXR $\alpha$; mRNA, messenger RNA; NF-kB, nuclear factor kappa-light-chain-enhancer of activated B cells; NR1H3, nuclear receptor subfamily, group $\mathrm{H}$, member 3; PBMC, peripheral blood mononuclear cells; PDK4, pyruvate dehydrogenase kinase, isozyme 4; qPCR, quantitative polymerase chain reaction; rpm, rounds per minute; Runx2, runt-related transcription factor 2; sTNFRSF1A, soluble tumor necrosis factor receptor 1; TBP, TATA box binding protein; TLDA, TaqMan LowDensity array; TLR, toll-like receptor; TNF $\alpha$, tumor necrosis factor alpha; TNFSF11, tumor necrosis factor ligand superfamily member 11; TNFRSF1A, tumor necrosis factor receptor superfamily, member 1A; TNFRSF11A, tumor necrosis factor receptor superfamily, member $11 \mathrm{~A}$ 


\section{Introduction}

The risk of developing chronic diseases is increased in older adults (1-5), and an elevated level of circulating inflammatory markers are often observed $(3,6)$. Growing evidence indicates that inflammatory markers, such as high-sensitive C-reactive protein (hs-CRP), interleukin 6 (IL6), and tumor necrosis factor alpha (TNFa), are associated with loss of muscle mass and muscle strength (7-15), possibly contributing to the development of sarcopenia $(13,16,17)$.

Dietary strategies to prevent the onset of chronic, low-grade inflammation are therefore suggested to improve several health outcomes and to prolong longevity among elderly $(3,6$, 18, 19). Foods, including fruits and vegetables, fish, whole grains and some vitamins, are shown to exert anti-inflammatory effects (2). The effects of dairy products on inflammatory markers are less clear (20). Some epidemiological evidence indicates that low-fat dairy products are inversely associated with the level of inflammatory markers among healthy adults (21-23), but the data are inconclusive (24). In randomized controlled trials a reduction in the circulating levels of TNF $\alpha$, IL6 and chemokine (C-C motif) ligand 2 (CCL2) have been shown after consuming dairy products in obese subjects $(25,26)$, but the data are not conclusive $(27,28)$. A reduction of the same inflammatory markers have been observed in subjects with the metabolic syndrome (29), but not in healthy adults $(30,31)$, nor in adult subjects with an elevated level of hs-CRP (32) after consuming dairy products.

High protein diets have increased in popularity, and these are widely used in combination with weight reduction (33) and in sports nutrition (34) to preserve muscle mass and promote muscle strength. Few have examined the possible effects of high protein diets on risk factors for chronic diseases $(24,35-37)$, among them level of inflammatory markers $(38,39)$. No negative effects on inflammatory markers are observed $(38,39)$, but long-term clinical studies are scarce (38-40).

In a double-blind randomized controlled intervention study, we investigated whether an increased daily intake of a low-fat, protein-enriched milk could alter markers of inflammation in peripheral mononuclear blood cells (PBMCs) and in serum among community dwelling elderly men and women above the age of 70 years with reduced muscle strength and functional performance. 


\section{Materials and methods}

\section{Study population and study design}

The present study is part of a research project were men and women ( $\geq 70$ years) living at home were recruited to a 12 week double-blind, randomized controlled intervention trial, conducted from August 2014 to September 2015 at Oslo and Akershus University College of Applied Sciences, Norway. The primary aim of this study was to investigate the effect of increased intake of protein-enriched milk on muscle mass and physical strength. A detailed description of participant recruitment, enrollment, selection criteria, and compliance are given elsewhere (41). In brief, 2820 subjects were invited to participate in the study. 438 subjects met to screening of which 388 were excluded. Thus, 50 older subjects, with either reduced hand grip strength $(<20 \mathrm{~kg}$ in women and $<30 \mathrm{~kg}$ in men), gait speed $<1 \mathrm{~m} / \mathrm{s}$, timed step stair test $\geq 8.4 \mathrm{~s}$ or timed five times sit to stand test $>12.5 \mathrm{~s}$, and otherwise weight stable and apparently healthy, were randomized. Among the exclusion criteria were a Mini-Mental State Examination score $<24$, a Mini Nutritional Assessment score $<17$ and high intakes of dairy products ( $\geq 4 \mathrm{dl} /$ day of milk, cultured milk and/or yoghurt). In total, 36 subjects completed the study. The intervention group received a protein-enriched milk ( $\mathrm{n}=17,2 \times 0.4 \mathrm{~L} / \mathrm{d} ; 2 \times 20$ g protein/d), whereas the control group received an isocaloric carbohydrate drink $(n=19,2 x$ $0.4 \mathrm{~L} / \mathrm{d}$ ), for 12 weeks. The subjects consumed the test drinks together with breakfast and the evening meal, and they were encouraged to maintain their habitual diet and physical activity level throughout the study period.

All subjects provided written informed consent, and we conducted the study according to the Declaration of Helsinki. We received approval for all procedures involving human subjects by the Regional Committees for Medical and Health Research Ethics, Health Region South East, Norway. The study was registered at Clinicaltrials.gov (ID no. NCT02218333).

\section{Study products}

TINE SA (Oslo, Norway) produced and provided the protein-enriched milk and the isocaloric control drink. The protein-enriched milk contained on average 5.0\% protein, $4.6 \%$ carbohydrates, $<0.1 \%$ fat and provided approximately $167 \mathrm{~kJ}(39 \mathrm{kcal}) / 100 \mathrm{~g}$. The control drink was prepared from carbohydrates (sugar, xantan gum and Maltosweet ${ }^{\mathrm{TM}}{ }^{\circledR}$ ). To give the control drink a milky appearance the producer added titandioksid (E171). Both drinks contained approximately $178 \mathrm{mg} / 100 \mathrm{~g}$ of calcium. 


\section{Blood sampling and sample preparation}

Venous blood samples were collected after an overnight fast $(\geq 12 \mathrm{~h})$ in BD Vacutainer ${ }^{\circledR}$ $\mathrm{CPT}^{\mathrm{TM}}$ cell preparation tubes with sodium heparin (Becton Dickenson, NJ, USA) and in silica gel tubes (Becton Dickenson Vacutainer Systems, Plymouth, UK) at baseline and after 12 weeks. Within two hours of blood collection PBMCs were collected by density gradient centrifugation of the blood samples (1636 $\mathrm{g}$ ) for $25 \mathrm{~min}$ at room temperature (RT). The cells were washed twice (300 g, $10 \mathrm{~min}$ at RT) in phosphate-buffered saline (PBS) without calcium chloride and magnesium chloride. After the last washing step, excess PBS was discarded. The pellet was dissolved in the remaining liquid and transferred to an Eppendorf tube, centrifuged $\left(13000 \mathrm{~g}, 3 \mathrm{~min}\right.$ at $\left.4^{\circ} \mathrm{C}\right)$ and frozen at $-80^{\circ} \mathrm{C}$ until further analysis. Serum samples were centrifuged $(1500 \mathrm{~g}, 15 \mathrm{~min}$ at RT) after being left on the bench top for at least $30 \mathrm{~min}$. Serum sample for the determination of cytokines were frozen at $-80^{\circ} \mathrm{C}$ until further analysis. Serum samples for the determination of hs-CRP, and EDTA-blood for the differential blood count, were sent to an accredited laboratory (Fürst Laboratories, Oslo, Norway) for further analysis.

\section{Isolation of RNA}

mRNA was isolated from thawed PBMCs using QiaCube from QIAGEN GmbH (Germany) in accordance with the protocol RNeasy Mini Kit with qiashredder and DNase digest (QIAGEN). Thirty $\mu$ high-quality mRNA was eluted in RNase free water and frozen at -80 ${ }^{\circ} \mathrm{C}$ until further analysis.

RNA quantity was measured using NanoDrop-1000 (NanoDrop Technologies, Inc., Delaware, USA), while RNA quality was checked with Aglient 2100 Bioanalyzer (Agilent Technologies, Inc., California, USA). All PBMC samples included in further analysis had a RIN-value above 9. One participant was excluded from further analysis due to low mRNA content in one of the PBMC samples.

\section{Synthesis of cDNA}

Complementary DNA (500 ng) was made using a RNA to cDNA kit from Applied Biosystems (Applied Biosystems, UK) in accordance with the manufacturer's protocol. Samples were stored at $-20{ }^{\circ} \mathrm{C}$ for further analysis.

RNA analysis/Real-time qPCR 
We analyzed mRNA levels of 48 genes using TaqMan Low-Density array (TLDA) cards from Applied Biosystems, UK (see supplementary table 1 for an overview of all genes analyzed). TLDA cards were run on a 7900 HT Applied Biosystems RT-qPCR machine (Applied Biosystems, UK). The cycle threshold values (Ct-values) were determined using SDS 2.4 (Applied Biosystems) and ExpressionSuite Sofware v1.0.3 (Applied Biosystems, UK). We normalized the Ct-values to TATA box binding protein $(T B P)$ and beta-2-microglobulin $(B 2 M)$ mRNA transcripts, and manually calculated relative changes in mRNA expression levels at baseline and at the end of the intervention $\left(2^{-\Delta \mathrm{Ct}}\right)$. Fold changes in mRNA transcripts from baseline to end of intervention were calculated by dividing $2^{-\Delta \text { Ctend }}$ with $2^{-\Delta \text { Ctbaseline }}$, using the $2^{-\Delta \Delta \mathrm{Ct}}$-method (42).

\section{CRP and cytokine measurements}

The serum levels of interleukin 10 (IL10), interferon gamma (IFNG) and TNFA were measured using a Magnetic Luminex Performance Assay (R\&D Systems Inc., Minneapolis, USA) in accordance with the protocol provided. IL6 and sTNFRSF1A were analyzed using Quantikine ELISA (R\&D Systems Inc., Minneapolis, USA) in accordance with the protocols provided. The levels of IL10 and IFNG were below the detection limit in the multiplex analysis. The inter-individual variation (CV) for IL6, TNF $\alpha$ and sTNFRSF1A were 6.5, 10.2 and $6.7 \%$, respectively. All samples were measured in duplicates.

\section{Statistics}

Subjects were stratified by gender and smoking prior to a 1:1 block-randomization. Power calculations were made on the primary outcome of the study (muscle mass), as described elsewhere (41). In all analysis, subjects with levels of hs-CRP above $>10 \mathrm{mg} / \mathrm{L}$ at baseline $(n=3)$ or at end of study $(n=1)$ were excluded as such levels may indicate an ongoing inflammation. In total, samples from 14 participants in the protein group and 17 participants in the control group were analyzed.

We used non-parametric tests for statistical analysis of data not normally distributed. MannWhitney-test was used to determine possible differences between the study groups, while Wilcoxon signed-rank test was used when investigating possible differences in variables between end of study and baseline within one study group. For normally distributed data, differences between study-groups at baseline were performed by the independent samples ttest. The Spearman correlation test was used to reveal possible correlations between the 
change in muscle mass and physical strength (chest press) with TNFA and sTNFRSF1A. Due to an explorative study design, correction for multiple testing was not performed. We considered a p-value of $<0.05$ statistically significant. SPSS statistical software, version 22 from Microsoft (SPSS, Inc., USA), was used for statistical calculations. 


\section{Results}

Table 1 shows baseline characteristics of the participants. There were no significant differences in gender, age, muscle mass, fat mass or BMI at baseline between the two study groups. As previously reported by Ottestad and colleagues (41), increased protein intake daily for 12 weeks did not significantly improve muscle mass, muscle strength or functional performance in healthy older and weight stable adults.

\section{Effects of protein-enriched milk on mRNA expression in PBMCs}

In the present study, we analyzed mRNA levels of inflammatory markers in PBMCs in order to test if an increased intake of a low-fat, protein-enriched milk daily would alter these markers in adults $>70$ years, when compared to an isocaloric intake of carbohydrates. We found that the change in mRNA levels of nuclear receptor subfamily, group $H$, member 3 $(N R 1 H 3)$, the gene that encodes for liver $\mathrm{X}$ receptor alpha $(\operatorname{LXR} \alpha)$, and $I F N G$ were significantly different between the two study groups after 12 weeks, whereas we observed no within-group changes for these genes in either of the two study groups (figure 1, panels A and B). In contrast, the mRNA level of TNFRSF1A decreased significantly (figure 2, panel A), whereas the mRNA level of dipeptidyl-peptidase 4 (DPP4) increased significantly (figure 2, panel B) in the control group after 12 weeks.

The mRNA levels of inflammatory genes, such as $I L 6, I L 1 \beta, I L 18, T N F \alpha, I L 10$ and interleukin 1 receptor antagonist (ILIRN) did not change significantly neither between, nor within the two study groups (supplementary tables 2 and 3).

In addition to inflammatory related genes, we investigated possible changes in genes involved in the regulation of muscle mass. We observed no significant changes in mRNA levels of runt-related transcription factor 2 (Runx2), growth arrest and DNA-damage-inducible alpha (Gadd45), tumor necrosis factor receptor superfamily member 11A (TNFRSF11A), tumor necrosis factor ligand superfamily member 11 (TNFSF11) or insulin-like growth factor 1 (IGF1) neither between, nor within the two study groups (supplementary tables 2 and 3).

Finally, we investigated possible changes in the distribution of cell types within the PBMC samples at baseline and end of study to be able to control for possible changes in the distribution of cell types. However, no differences were found in the distribution of cell types after the intervention period (supplementary table 4). 


\section{Effects of protein-enriched milk on serum levels of inflammatory markers}

Based on the results from the mRNA analysis, we analyzed the effects of protein-enriched milk consumption on serum levels of sTNFRSF1A, TNFA and IL6. In contrast to the mRNA data, we found that the serum level of sTNFRSF1A increased significantly in both study groups ( $\mathrm{p}=0.022$ in the protein group, $\mathrm{p}=0.009$ in the control group), whereas the serum level of TNF $\alpha$ increased in the control group ( $\mathrm{p}=0.03)$, but with no statistically significant differences between the two study groups. The serum levels of IL6, hs-CRP and the ratio TNF $\alpha /$ sTNFRSF1A were not significantly different, neither within nor between the two study groups (table 2).

We have previously reported that combining the two study groups, a significant improvement in muscle mass and chest press was observed from baseline to end of study (41). In the present study, we observed a significant increase in serum levels of TNFA $(p=0.001)$ and sTNFRSF1A ( $\mathrm{p}=0.049)$ from baseline to end of study when combining the two study groups $(n=31)$. However, we observed no relationship between the serum level of TNFA and muscle mass, $r=-0.12(p=0.54)$, or chest press, $r=-0.13(p=0.49)$ in the groups combined $(n=31)$. Nor did we observed any relationship between changes in the serum level of sTNFRSF1A and muscle mass, $r=0.16(p=0.40)(n=)$ or chest press, $r=0.15(p=0.43)$ in the groups combined $(n=31)$. 


\section{Discussion}

In the present study, we explored the impact of adding a daily intake of low-fat, high-protein milk to the regular diet of community-dwelling subjects $>70$ years of age with reduced muscle strength and/or physical function, for 12 weeks, on inflammatory markers. Our data indicate that the intake of this milk had minor effects on mRNA expression and circulating inflammatory markers, compared to an isocaloric control drink containing carbohydrates only.

In the majority of studies where possible effects of consuming dairy products $(25,27,28,43)$, or high-protein diets $(38,39,44-46)$ on circulating inflammatory markers were investigated, no significant effects on circulating markers, such as hs-CRP, IL6 or TNF $\alpha$ were observed, supporting the results of the present study. We did observe a significant increase in the serum level of TNFa, but only in the control group receiving carbohydrates, indicating an increased TNF $\alpha$ activity in the control group. The serum level of sTNFRSF1A increased significantly in both groups after the intervention with no statistically significant changes between the two groups. The increased level of sTNFRSF1A in the protein group is in accordance with Van Meijl and colleagues, who also found an increased level of sTNFRSF1A after providing overweight subjects ( $\mathrm{n}=35$, mean age $49.5 \mathrm{yrs}$ ) with low-fat dairy products ( $500 \mathrm{ml}$ milk and $150 \mathrm{~g}$ yoghurt, equals $\sim 24 \mathrm{~g}$ protein, $1.5 \mathrm{MJ} /$ day) daily for eight weeks. In contrast, they did not observe this effect in the control group who received $600 \mathrm{ml}$ fruit juice and three fruit biscuits daily (1.7 MJ/day) (25). Van Meijl and colleagues suggested that these effects may be related to the content of calcium, as calcium has been shown to enhance the TNF $\alpha$-signaling in human embryonic kidney cells (47). In the present study, the calcium content was similar in the two drinks, suggesting that this effect may be independent of calcium.

Elevated circulating levels of hs-CRP, TNF $\alpha$, IL6 and sTNFRSF1A have been associated with a decline in muscle mass $(8-10,12)$ and increased mortality in older adults $(48,49)$, but few randomized controlled trials have been performed investigating possible effects of consuming protein with the level of inflammatory markers in combination with muscle mass and muscle strength $(13,50)$. Lower rates of muscle protein synthesis have also been associated with an upregulation of the NF- $\kappa$ B pathway, a key regulator of inflammation (13). Both TNFA and

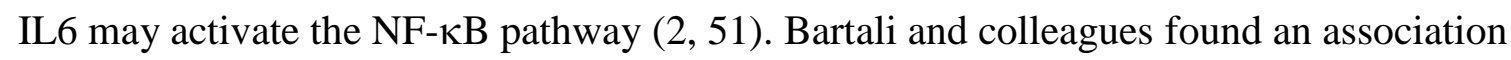
between a low protein intake, high levels of TNF $\alpha$, IL6 and CRP and muscle strength in older subjects (13). We have previously reported that the additional intake of $40 \mathrm{~g}$ protein or an isocaloric carbohydrate drink daily increased chest press after 12 weeks of intervention, in the 
groups combined (41). We therefore investigated possible correlations between changes in muscle mass and chest press with changes in circulating levels of TNFA and sTNFRSF1A. However, we observed no correlations between these parameters. In contrast to the subjects included in the study of Bartali and colleagues (13), subjects included in the present study already had a protein intake within the recommended levels (52) at baseline (1.0 $\pm 0.3 \mathrm{~g})$ (41). This may be one explanation for observing no associations between changes in muscle mass, chest press and circulating levels of TNF $\alpha$ or sTNFRSF1A when additional protein was provided throughout the day.

After the intervention period, we observed a statistically significant difference in mRNA expression levels between the two study groups for two out of the 44 genes analyzed; $N R 1 H 3$ and INFG. The mRNA levels of both $N R I H 3$ and INFG increased slightly in the protein group, with the opposite effect in the control group (figure 1, panel A and B). LXR $\alpha$ plays a central role in the transcriptional regulation of metabolism and inflammation (53), and LXR $\alpha$ activation has been shown to reduce inflammation by decreasing the level of Th-1 cytokine release, among them the pro-inflammatory cytokine INFG, in stimulated T-cells (54). Alternations in the endogenous regulatory system for LXR $\alpha$ in immune cells may potentially lead to immune related diseases (55). LXR $\alpha$ also have an important role in promoting the elimination of excessive cholesterol from the cell $(53,55)$. In HepG2 cells, an upregulation of the mRNA expression level of $N R 1 H 3$ has been observed after supplementation with branched chained amino acids (BCAA), suggesting that BCAA may improve glucose metabolism (56). INFG coordinates a diverse array of cellular programs within the immune system, and it is believed to induce a Th-1 cytokine release (57). In the present study, expression of $N R I H 3$ does not seem to suppress the expression of $I N F G$ as previously shown in stimulated T-cells (54) as the mRNA levels of INFG increased in the protein group, but decreased in the control group. Based on the present results and lack of human studies, it is difficult to interpret the physiological meaning of the observed differences in the present study. To our knowledge, few, if any, have previously investigated the effects of long-term dairy protein or high-protein diets on the mRNA expression levels of NR1H3 or INFG in healthy, elderly humans.

In the protein group, we found no statistically significant changes in mRNA levels of any of the genes analyzed. These results are in accordance with data presented by Labonté and colleagues, who found no differences in mRNA expression levels of CCL2, IL18, IL6, IL1 $\beta$ or TNFA in whole blood after consuming three servings of dairy products daily, compared to an 
isocaloric amount of fruit- and vegetable juices, cashews and cookies (32). Fifty-three subjects with low-grade systemic inflammation were included in this randomized controlled trial (32). Van Loan and colleagues (27) also performed a randomized controlled trial, investigating possible effects of a high vs a low intake of dairy products daily (4 vs 0.5 serving/day). Seventy-one obese subjects were included in that study where they observed no changes in mRNA levels in adipose tissue of $T N F \alpha, I L 6, C C L 2, I L 1 \beta, I L 10$ or $I L 15$ after the intervention period, supporting our mRNA data. Low-fat milk, yoghurt and full-fat cheese were provided in these studies $(27,32)$.

In the control group, we observed a $\sim 0.6$ fold downregulation of TNFRSF1A mRNA expression (figure 2, panel A) and a 1.3 fold upregulation of DDP4 mRNA expression (figure 2, panel B), with no significant differences between the two groups. The upregulation of DDP4 may be related to the increased intake of carbohydrate in the control group. Simple carbohydrates may increase the activation of the $\mathrm{NF}-\kappa \mathrm{B}$ pathway $(2,51)$, and both TNFRSF1A and DDP4 are able to induce the transcription of inflammatory genes through this pathway (49). However, we observed no changes in target genes of the NF- $\kappa \mathrm{B}$ pathway (58), such as IL6, TNF $\alpha, I L 8, C C L 2$ and chemokine (C-C motif) ligand 3 (CCL3), in the control group. The down-regulation of TNFRSF1A gene expression was in contrast to the increased serum level of sTNFRSF1A. Many other tissues (e.g. endothelial cell, adipose tissue and tissue macrophages) than PBMCs, may also contribute to the circulating levels of inflammatory markers, making the comparison between serum and PBMC levels difficult.

There are several methodological differences among the studies where intakes of dairy products/high-protein diets and potential implications on health are investigated, possibly explaining some of the conflicting results. The above-mentioned studies were performed in different groups (subjects with low-grade inflammation, the metabolic syndrome or obese subjects), different products were provided in the control groups, different levels and sources of protein were given and the metabolic status of the subjects included differed $(39,59-61)$. In addition, dairy products are a heterogeneous group of foods that may exert different health effects. Most dairy products contain high levels of calcium, which is a component suggested to be able to suppress inflammation by inhibiting the production of inflammatory substances from adipose tissue through the inhibition of calcitriol $(27,29,62)$. In the present study, we supplied an equal amount of calcium to both groups, in an attempt to nullifying such an effect. 
This may be a possible explanation for the lack of differences observed between the two study groups.

The major limitations of the present study were the few subjects included in the final analysis $(n=31)$, that only a selection of markers known to be involved in chronic-low grade inflammation were analyzed, and that we measured the selected markers at mRNA level only. Moreover, the present study did not include measurement of postprandial gene expression levels, which could have provided important insight into the acute response to the consumption of dairy protein compared to carbohydrates. Major strengths were the doubleblind randomized controlled design, the strictly controlled methodology, the isocaloric composition of the test products and the very high compliance to the experimental procedure of the subjects completing the study.

\section{Conclusion}

In the present study, we investigated possible effects of consuming a low-fat, protein-enriched milk, compared to an isocaloric carbohydrate drink, in older adults with reduced physical strength and/or functional performance, on mRNA levels in PBMCs and serum levels of selected inflammatory markers. Altogether, the results from the present study indicate that consuming low fat, protein-enriched milk for 12 weeks had minor effects on these markers, compared to an isocaloric control drink. 


\section{Acknowledgements}

We want to acknowledge all subjects volunteering to participate in this study, and Ellen Raael, Navida-Akhter Sheikh, Marit Sandvik, Linn Øyri, Kristin S. Sandvei, Kristin Torvik and Grete Skjegstad for valuable assistance in this project. I.O, T.R, P.O.I, B.S.S, K.R, A.S.B, S.M.U and K.B.H designed the study. I.O, G.O.G and A.S.B conducted the research. G.O.G performed the statistical analysis. G.O.G, S.M.U and K.B.H wrote the paper. All authors read and approved the final manuscript. 


\section{Financial disclosure}

The Research Council of Norway (225258/E.40), Throne Holst Foundation for Nutrition Research (University of Oslo) and TINE SA supported this work. The protein-enriched milk and the isocaloric carbohydrate drink were provided by TINE SA, Oslo, Norway, where G.O.G and A.S.B are researchers employed. They have no financial interest to declare. I.O., P.O.I., B.S.S., K.B.H. and S.M.U. report no conflict of interest.

K.B.H. has received research grant from TINE SA, Mills DA, Olympic Seafood, Amgen, Sanofi and Pronova. S.M.U. has received research grant from TINE SA, Mills DA and Olympic Seafood. P.O.I. has received grant from Mills DA. K.R. has received research grants and honoraria from Abbot, Apotek 1, Amgen, Genzyme, Melk.no, Mills DA, MSD, The Norwegian Medical Association, The Norwegian Directorate for Health, Oslo Economics, Pfizer, Sanofi, The Norwegian Medicines Agency. None of these grants or honoraria are related to the contents of this manuscript. 


\section{References}

1. Chung HY, Lee EK, Choi YJ, Kim JM, Kim DH, Zou Y, et al. Molecular inflammation as an underlying mechanism of the aging process and age-related diseases. $\mathbf{J}$ Dent Res. 2011;90(7):830-40.

2. Calder PC, Ahluwalia N, Brouns F, Buetler T, Clement K, Cunningham K, et al. Dietary factors and low-grade inflammation in relation to overweight and obesity. Br J Nutr. 2011;106 Suppl 3:S5-78.

3. Singh T, Newman AB. Inflammatory markers in population studies of aging. Ageing research reviews. 2011;10(3):319-29.

4. Simon AK, Hollander GA, McMichael A. Evolution of the immune system in humans from infancy to old age. Proc Biol Sci. 2015;282(1821):20143085.

5. Guarner V, Rubio-Ruiz ME. Low-grade systemic inflammation connects aging, metabolic syndrome and cardiovascular disease. Interdisciplinary topics in gerontology. 2015;40:99-106.

6. Franceschi C. Inflammaging as a major characteristic of old people: can it be prevented or cured? Nutr Rev. 2007;65(12 Pt 2):S173-6.

7. Legrand D, Adriaensen W, Vaes B, Mathei C, Wallemacq P, Degryse J. The relationship between grip strength and muscle mass (MM), inflammatory biomarkers and physical performance in community-dwelling very old persons. Arch Gerontol Geriatr. 2013;57(3):345-51.

8. Schaap LA, Pluijm SM, Deeg DJ, Harris TB, Kritchevsky SB, Newman AB, et al. Higher inflammatory marker levels in older persons: associations with 5-year change in muscle mass and muscle strength. J Gerontol A Biol Sci Med Sci. 2009;64(11):1183-9.

9. Visser M, Pahor M, Taaffe DR, Goodpaster BH, Simonsick EM, Newman AB, et al. Relationship of interleukin-6 and tumor necrosis factor-alpha with muscle mass and muscle strength in elderly men and women: the Health ABC Study. J Gerontol A Biol Sci Med Sci. 2002;57(5):M326-32.

10. Cesari M, Penninx BW, Pahor M, Lauretani F, Corsi AM, Rhys Williams G, et al. Inflammatory markers and physical performance in older persons: the InCHIANTI study. J Gerontol A Biol Sci Med Sci. 2004;59(3):242-8.

11. Marzetti E, Landi F, Marini F, Cesari M, Buford TW, Manini TM, et al. Patterns of circulating inflammatory biomarkers in older persons with varying levels of physical performance: a partial least squares-discriminant analysis approach. Frontiers in medicine. 2014;1:27.

12. Aleman H, Esparza J, Ramirez FA, Astiazaran H, Payette H. Longitudinal evidence on the association between interleukin- 6 and C-reactive protein with the loss of total appendicular skeletal muscle in free-living older men and women. Age Ageing. 2011;40(4):469-75.

13. Bartali B, Frongillo EA, Stipanuk MH, Bandinelli S, Salvini S, Palli D, et al. Protein intake and muscle strength in older persons: does inflammation matter? J Am Geriatr Soc. 2012;60(3):480-4.

14. Taaffe DR, Harris TB, Ferrucci L, Rowe J, Seeman TE. Cross-sectional and prospective relationships of interleukin- 6 and C-reactive protein with physical performance in elderly persons: MacArthur studies of successful aging. J Gerontol A Biol Sci Med Sci. 2000;55(12):M709-15.

15. Vina J, Tarazona-Santabalbina FJ, Perez-Ros P, Martinez-Arnau FM, Borras C, OlasoGonzalez G, et al. Biology of frailty: Modulation of ageing genes and its importance to prevent age-associated loss of function. Mol Aspects Med. 2016. 
16. Beyer I, Mets T, Bautmans I. Chronic low-grade inflammation and age-related sarcopenia. Curr Opin Clin Nutr Metab Care. 2012;15(1):12-22.

17. Laviano A, Gori C, Rianda S. Sarcopenia and nutrition. Adv Food Nutr Res. 2014;71:101-36.

18. Kritchevsky SB, Cesari M, Pahor M. Inflammatory markers and cardiovascular health in older adults. Cardiovasc Res. 2005;66(2):265-75.

19. Panickar KS, Jewell DE. The beneficial role of anti-inflammatory dietary ingredients in attenuating markers of chronic low-grade inflammation in aging. Horm Mol Biol Clin Investig. 2015;23(2):59-70.

20. Draganidis D, Karagounis LG, Athanailidis I, Chatzinikolaou A, Jamurtas AZ, Fatouros IG. Inflammaging and Skeletal Muscle: Can Protein Intake Make a Difference? J Nutr. 2016.

21. Panagiotakos DB, Pitsavos CH, Zampelas AD, Chrysohoou CA, Stefanadis CI. Dairy products consumption is associated with decreased levels of inflammatory markers related to cardiovascular disease in apparently healthy adults: the ATTICA study. J Am Coll Nutr. 2010;29(4):357-64.

22. Azadbakht L, Mirmiran P, Esmaillzadeh A, Azizi F. Dairy consumption is inversely associated with the prevalence of the metabolic syndrome in Tehranian adults. Am J Clin Nutr. 2005;82(3):523-30.

23. Esmaillzadeh A, Azadbakht L. Dairy consumption and circulating levels of inflammatory markers among Iranian women. Public Health Nutr. 2010;13(9):1395-402.

24. Rashidi Pour Fard N, Karimi M, Baghaei MH, Haghighatdoost F, Rouhani MH, Esmaillzadeh A, et al. Dairy consumption, cardiovascular risk factors and inflammation in elderly subjects. ARYA atherosclerosis. 2015;11(6):323-31.

25. van Meijl LE, Mensink RP. Effects of low-fat dairy consumption on markers of lowgrade systemic inflammation and endothelial function in overweight and obese subjects: an intervention study. Br J Nutr. 2010;104(10):1523-7.

26. Zemel MB, Sun X, Sobhani T, Wilson B. Effects of dairy compared with soy on oxidative and inflammatory stress in overweight and obese subjects. Am J Clin Nutr. 2010;91(1):16-22.

27. Van Loan MD, Keim NL, Adams SH, Souza E, Woodhouse LR, Thomas A, et al. Dairy Foods in a Moderate Energy Restricted Diet Do Not Enhance Central Fat, Weight, and Intra-Abdominal Adipose Tissue Losses nor Reduce Adipocyte Size or Inflammatory Markers in Overweight and Obese Adults: A Controlled Feeding Study. J Obes. 2011;2011:989657.

28. Wennersberg MH, Smedman A, Turpeinen AM, Retterstol K, Tengblad S, Lipre E, et al. Dairy products and metabolic effects in overweight men and women: results from a 6-mo intervention study. Am J Clin Nutr. 2009;90(4):960-8.

29. Stancliffe RA, Thorpe T, Zemel MB. Dairy attentuates oxidative and inflammatory stress in metabolic syndrome. Am J Clin Nutr. 2011;94(2):422-30.

30. Drouin-Chartier JP, Gagnon J, Labonte ME, Desroches S, Charest A, Grenier G, et al. Impact of milk consumption on cardiometabolic risk in postmenopausal women with abdominal obesity. Nutrition journal. 2015;14:12.

31. Tricon S, Burdge GC, Jones EL, Russell JJ, El-Khazen S, Moretti E, et al. Effects of dairy products naturally enriched with cis-9,trans-11 conjugated linoleic acid on the blood lipid profile in healthy middle-aged men. Am J Clin Nutr. 2006;83(4):744-53.

32. Labonte ME, Cyr A, Abdullah MM, Lepine MC, Vohl MC, Jones P, et al. Dairy product consumption has no impact on biomarkers of inflammation among men and women with low-grade systemic inflammation. J Nutr. 2014;144(11):1760-7.

33. Hu FB. Protein, body weight, and cardiovascular health. Am J Clin Nutr. 2005;82(1 Suppl):242s-7s. 
34. Goisser S, Kemmler W, Porzel S, Volkert D, Sieber CC, Bollheimer LC, et al. Sarcopenic obesity and complex interventions with nutrition and exercise in communitydwelling older persons--a narrative review. Clin Interv Aging. 2015;10:1267-82.

35. Wolfe BM. Potential role of raising dietary protein intake for reducing risk of atherosclerosis. Can J Cardiol. 1995;11 Suppl G:127g-31g.

36. Clifton PM, Keogh J. Metabolic effects of high-protein diets. Current atherosclerosis reports. 2007;9(6):472-8.

37. Schwingshackl L, Hoffmann G. Long-term effects of low-fat diets either low or high in protein on cardiovascular and metabolic risk factors: a systematic review and metaanalysis. Nutrition journal. 2013;12:48.

38. Santesso N, Akl EA, Bianchi M, Mente A, Mustafa R, Heels-Ansdell D, et al. Effects of higher- versus lower-protein diets on health outcomes: a systematic review and metaanalysis. Eur J Clin Nutr. 2012;66(7):780-8.

39. Teunissen-Beekman KF, Dopheide J, Geleijnse JM, Bakker SJ, Brink EJ, de Leeuw $\mathrm{PW}$, et al. Dietary proteins improve endothelial function under fasting conditions but not in the postprandial state, with no effects on markers of low-grade inflammation. Br J Nutr. 2015;114(11):1819-28.

40. Ziegler CC, Sidani MA. Diets for successful aging. Clin Geriatr Med. 2011;27(4):577-

89.

41. Inger Ottestad ATL, Gyrd Omholt Gjevestad, Håvard Hamarsland, Jūratė Šaltytė Benth, Lene Frost Andersen, Asta Bye, Anne Sofie Biong, Kjetil Retterstøl, Per Ole Iversen, Truls Raastad, Stine M Ulven, Kirsten B Holven. Intake of a protein-enriched milk and effects on muscle mass and strength. A 12-week randomized placebo controlled trial among community-dwelling older adults. J Nutr Health Aging. In press.

42. Livak KJ, Schmittgen TD. Analysis of relative gene expression data using real-time quantitative PCR and the 2(-Delta Delta C(T)) Method. Methods. 2001;25(4):402-8.

43. Bohl M, Bjornshave A, Gregersen S, Hermansen K. Whey and Casein Proteins and Medium-Chain Saturated Fatty Acids from Milk Do Not Increase Low-Grade Inflammation in Abdominally Obese Adults. The review of diabetic studies : RDS. 2016.

44. Pal S, Ellis V. The chronic effects of whey proteins on blood pressure, vascular function, and inflammatory markers in overweight individuals. Obesity (Silver Spring, Md). 2010;18(7):1354-9.

45. Ballard KD, Bruno RS, Seip RL, Quann EE, Volk BM, Freidenreich DJ, et al. Acute ingestion of a novel whey-derived peptide improves vascular endothelial responses in healthy individuals: a randomized, placebo controlled trial. Nutrition journal. 2009;8:34.

46. Rebholz CM, Reynolds K, Wofford MR, Chen J, Kelly TN, Mei H, et al. Effect of soybean protein on novel cardiovascular disease risk factors: a randomized controlled trial. Eur J Clin Nutr. 2013;67(1):58-63.

47. Tomsig JL, Sohma H, Creutz CE. Calcium-dependent regulation of tumour necrosis factor-alpha receptor signalling by copine. Biochem J. 2004;378(Pt 3):1089-94.

48. Varadhan R, Yao W, Matteini A, Beamer BA, Xue QL, Yang H, et al. Simple biologically informed inflammatory index of two serum cytokines predicts 10 year all-cause mortality in older adults. J Gerontol A Biol Sci Med Sci. 2014;69(2):165-73.

49. Wertz IE. TNFR1-activated NF-kappaB signal transduction: regulation by the ubiquitin/proteasome system. Curr Opin Chem Biol. 2014;23:71-7.

50. Dawson BM, Axford S. Nutrition As a Part of Healthy Aging and Reducing Cardiovascular Risk: Improving Functionality in Later Life Using Quality Protein, with Optimized Timing and Distribution. Semin Thromb Hemost. 2014. 
51. Minihane AM, Vinoy S, Russell WR, Baka A, Roche HM, Tuohy KM, et al. Lowgrade inflammation, diet composition and health: current research evidence and its translation. Br J Nutr. 2015;114(7):999-1012.

52. Council TN. Nordic nutrition recommendations: NNR 2004 : integrating nutrition and physical activity. ISBN 92-893-1062-6. 2004.

53. Zelcer N, Tontonoz P. Liver X receptors as integrators of metabolic and inflammatory signaling. J Clin Invest. 2006;116(3):607-14.

54. Walcher D, Kummel A, Kehrle B, Bach H, Grub M, Durst R, et al. LXR activation reduces proinflammatory cytokine expression in human $\mathrm{CD} 4$-positive lymphocytes.

Arterioscler Thromb Vasc Biol. 2006;26(5):1022-8.

55. Spann NJ, Glass CK. Sterols and oxysterols in immune cell function. Nat Immunol. 2013;14(9):893-900.

56. Higuchi N, Kato M, Miyazaki M, Tanaka M, Kohjima M, Ito T, et al. Potential role of branched-chain amino acids in glucose metabolism through the accelerated induction of the glucose-sensing apparatus in the liver. J Cell Biochem. 2011;112(1):30-8.

57. Schoenborn JR, Wilson CB. Regulation of interferon-gamma during innate and adaptive immune responses. Adv Immunol. 2007;96:41-101.

58. Bonizzi G, Karin M. The two NF-kappaB activation pathways and their role in innate and adaptive immunity. Trends Immunol. 2004;25(6):280-8.

59. Labonte ME, Couture P, Richard C, Desroches S, Lamarche B. Impact of dairy products on biomarkers of inflammation: a systematic review of randomized controlled nutritional intervention studies in overweight and obese adults. Am J Clin Nutr. 2013;97(4):706-17.

60. Da Silva MS, Rudkowska I. Dairy products on metabolic health: current research and clinical implications. Maturitas. 2014;77(3):221-8.

61. Lopez-Legarrea P, de la Iglesia R, Abete I, Navas-Carretero S, Martinez JA, Zulet MA. The protein type within a hypocaloric diet affects obesity-related inflammation: the RESMENA project. Nutrition. 2014;30(4):424-9.

62. Zemel MB. Proposed role of calcium and dairy food components in weight management and metabolic health. The Physician and sportsmedicine. 2009;37(2):29-39. 


\section{Figure legends}

Figure 1. mRNA levels in PBMCs of NRIH3 [A] and IFNG [B] expressed as fold change from baseline after 12 weeks of supplementaion with proteins $(n=14)$ or carbohydrates (control, $n=17[\mathrm{~A}]$ and n=16 [B]). Data are shown at an individual level, with one symbol (triangle, circle, sauare) representing one individual. The horizontal lines represent the median with interquartile range.

Figure 2. mRNA levels in PBMCs of TNFRSF1A [A] and DDP4 [B] expressed as fold change from baseline after 12 weeks of supplementation with proteins $(n=14)$ or carbohydrates (control, $\mathrm{n}=17$ ). Data are shown at an individual level, with one symbol (triangle, circle, sauare) representing one individual. The horizontal lines represent the median with interquartile range. 
Figure 1

A

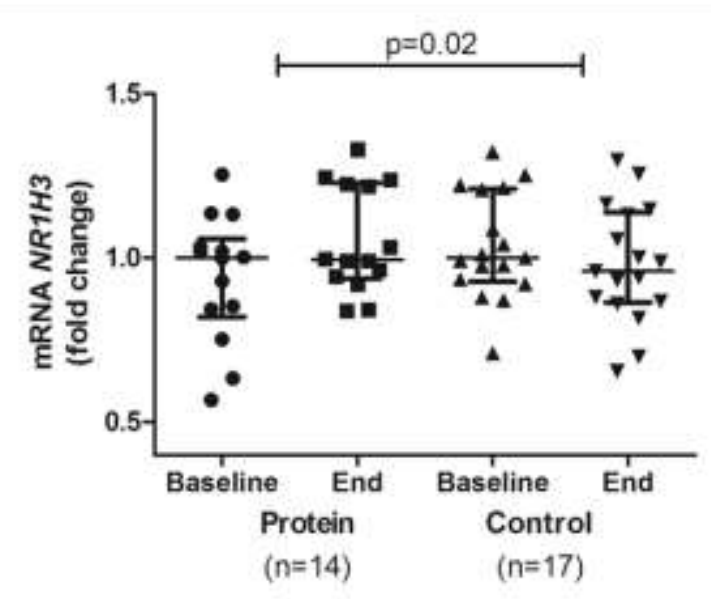

B

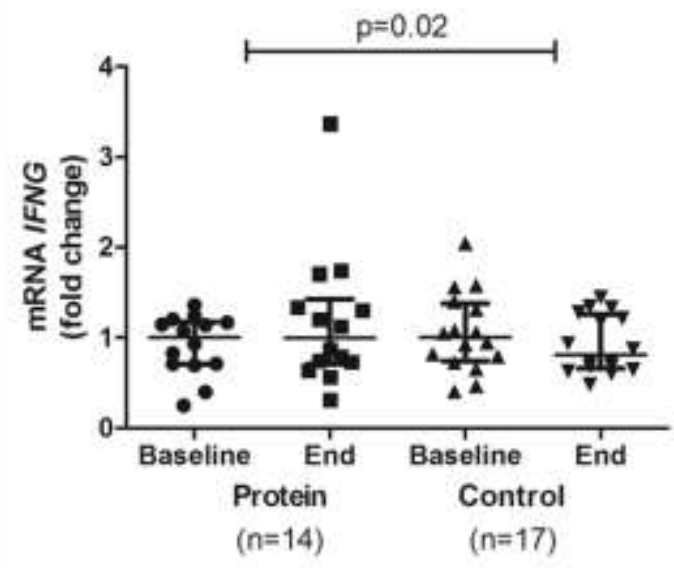

Figure 2

A

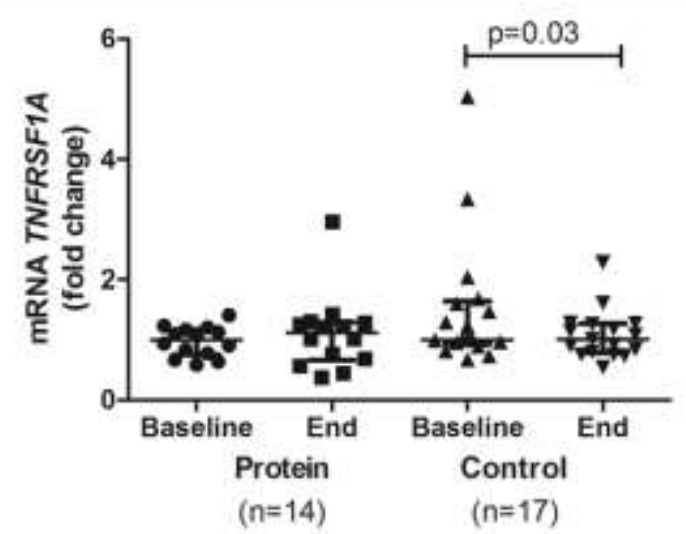

B

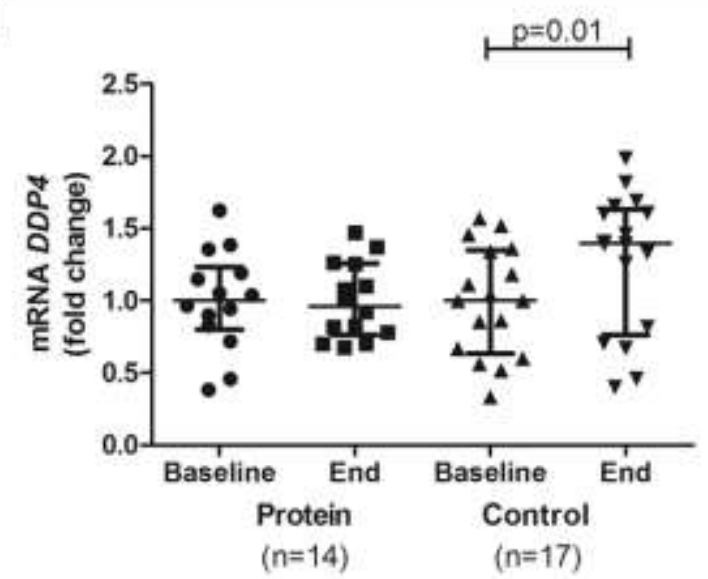


Table 1 Baseline characteristics.

\begin{tabular}{lcc}
\hline & $\begin{array}{c}\text { Protein group } \\
(\mathrm{n}=14)\end{array}$ & $\begin{array}{c}\text { Control group } \\
(\mathrm{n}=17)\end{array}$ \\
\hline Gender (n men/n women) & $4 / 10$ & $5 / 12$ \\
Age (yrs) & $76.9 \pm 4.9$ & $77.7 \pm 4.8$ \\
Muscle mass $(\mathrm{kg})$ & $43.7 \pm 0.8$ & $44.1 \pm 0.9$ \\
Fat mass $(\mathrm{kg})$ & $28.8 \pm 0.9$ & $29.9 \pm 0.9$ \\
BMI $\left(\mathrm{kg} / \mathrm{m}^{2}\right)$ & $27.1 \pm 3.8$ & $26.4 \pm 4.9$ \\
\hline
\end{tabular}

Data are presented as mean \pm SD. No significant differences were observed between the two groups at baseline. 
Table 2 Effects of protein-enriched milk and isocaloric control drink on circulating inflammatory markers and body composition.

\begin{tabular}{|c|c|c|c|c|c|c|c|c|c|}
\hline & \multicolumn{4}{|c|}{ Protein group $(n=14)$} & \multicolumn{4}{|c|}{ Control group $(n=17)$} & \multirow[b]{2}{*}{$\mathrm{p}$-value ${ }^{2}$} \\
\hline & $\begin{array}{c}\text { Median } \\
\text { (min-max) } \\
\text { baseline }\end{array}$ & $\begin{array}{c}\text { Median } \\
\text { (min.max) } \\
\text { end of study }\end{array}$ & $\begin{array}{c}\Delta \text { median } \\
(\min -\max )\end{array}$ & $\begin{array}{c}\mathrm{p}^{-} \\
\text {value }^{1}\end{array}$ & $\begin{array}{l}\text { Median (min- } \\
\text { max) baseline }\end{array}$ & $\begin{array}{c}\text { Median } \\
\text { (min.max) } \\
\text { end of study }\end{array}$ & $\begin{array}{c}\Delta \text { median } \\
(\min -\max )\end{array}$ & $\begin{array}{c}\mathrm{p}- \\
\text { value }^{1}\end{array}$ & \\
\hline hs-CRP (mg/L) & $1.5(0.4-6.0)$ & $1.7(0.9-9.0)$ & $0.5(-5.1-7.6))$ & 0.10 & $1.1(0.3-5.0)$ & $1.5(0.2-4.7)$ & $0.1(-1.3-1.3)$ & 0.67 & 0.07 \\
\hline IL6 (pg/ml) & $1.7(1.0-4.5)$ & $1.9(1.0-4.8)$ & $-0.1(-1.7-1.6)$ & 0.40 & $1.7(0.6-10.7)$ & $2.0(0.5-7.0)$ & $0.02(-2.8-3.7)$ & 0.91 & 0.81 \\
\hline $\mathrm{TNFA}(\mathrm{pg} / \mathrm{ml})$ & $3.5(1.2-6.4)$ & $3.5(1.4-5.4)$ & $1.0(0.6-1.3)$ & 0.46 & $3.6(0.6-18.2)$ & $4.1(1.1-12.3)$ & $1.1(0.7-1.8)$ & 0.03 & 0.53 \\
\hline TNFRSF1A (pg/ml) & $\begin{array}{c}992.5 \\
(689.3-1511.1)\end{array}$ & $\begin{array}{c}1087.4 \\
(825.4-1004.4)\end{array}$ & $\begin{array}{c}-117.7 \\
(213.3-163.8)\end{array}$ & 0.02 & $\begin{array}{c}1036.6 \\
(133.3-2430.7)\end{array}$ & $\begin{array}{c}1086.2 \\
(789.3-2224.5)\end{array}$ & $\begin{array}{c}-49.6 \\
(-1057.0-206.2)\end{array}$ & 0.01 & 0.69 \\
\hline $\mathrm{TNF} \alpha / \mathrm{sTNFRSF} 1 \mathrm{~A}$ ratio $\left(10^{-4}\right)$ & $3.6(1.3-5.0)$ & $2.9(1.3-5.5)$ & $-6.3(-11.1-48.7)$ & 0.27 & $3.2(0.6-33.0)$ & $3.3(1.0-5.5)$ & $-7.4(-75.9-997)$ & 0.69 & 0.55 \\
\hline Lean body mass (kg) & $41.8(34.6-56.7)$ & $42.4(34.7-57.5)$ & $0.4(-0.13-0.2)$ & 0.12 & $41.5(32.6-65.5)$ & $42.1(33.5-66.6)$ & $0.6(-0.1-0.3)$ & 0.03 & 0.45 \\
\hline Fat mass $(\mathrm{kg})$ & $28.6(15.1-45.3)$ & $27.8(15.0-46.0)$ & $0.083(-1.2-1.2)$ & 0.64 & $24.6(12.9-49.0)$ & $25.3(13.0-51.5)$ & $0.74(-3.3-2.5)$ & 0.15 & 0.18 \\
\hline
\end{tabular}

${ }^{1}$ changes from baseline were analyzed using Wilcoxon signed test

2 between group effects were analyzed using Mann-Whitney U-test

$\Delta$ mean difference between baseline and end of study 
Table S1 All genes analysed in the study.

\begin{tabular}{|c|c|c|c|c|}
\hline Gene & Abbreviation & \begin{tabular}{|l|} 
Entrez \\
Gene \\
Number \\
\end{tabular} & Assay ID & Function \\
\hline Beta-2-Microglobulin & B2M & 567 & Hs00187842_m1 & $\begin{array}{l}\text { Component of the class I major } \\
\text { histocompatibility complex (used as } \\
\text { housekeeping gene) }\end{array}$ \\
\hline Chemokine (C-C-Motif) Ligand 2 & CCL2 & 6347 & Hs00234140_m1 & $\begin{array}{l}\text { Involved in chemotactic activity for } \\
\text { monocytes and basophils, binding to } \\
\text { CCR2 and CCR } 4\end{array}$ \\
\hline Chemokine (C-X-C-Motif) Ligand 16 & CXCL16 & 58191 & Hs00222859_m1 & $\begin{array}{l}\text { Involved in the migration of cells, a } \\
\text { chemoattractant }\end{array}$ \\
\hline Chitinase-3-Like 1 & CHI3L1 & 1116 & Hs01072228_m1 & $\begin{array}{l}\text { Involved in inflammation and } \\
\text { extracellular tissue remodeling }\end{array}$ \\
\hline Dipeptidyl-Peptidase 4 & DPP4 & 1803 & Hs00897391_m1 & Involved in glucose metabolism \\
\hline Fas Cell Surface Death Receptor & FAS & 355 & Hs00163653_m1 & Involved in apoptosis \\
\hline F-box Protein 32 & FBXO32 & 114907 & Hs01041408_m1 & Involved in muscle atrophy \\
\hline Forkhead Box O1 & FOXO1 & 2308 & Hs01054576_m1 & $\begin{array}{l}\text { Transcription factor, regulating whole } \\
\text { body energy metabolism }\end{array}$ \\
\hline Glucuronidase, Beta & GUSB & 2990 & Hs00939627_m1 & $\begin{array}{l}\text { Involved in the degradation of dermatan } \\
\text { and keratan sulfates (included as a } \\
\text { potential housekeeping gene) }\end{array}$ \\
\hline Glyceraldehyd-3-Phosphate Dehydrogenase & GAPDH & 2597 & Hs02758991_g1 & $\begin{array}{l}\text { Involved in the break down glucose for } \\
\text { energy and carbon molecules (included } \\
\text { as a potential housekeeping gene) }\end{array}$ \\
\hline $\begin{array}{l}\text { Growth Arrest AND DNA-Damage-Inducible, } \\
\text { Alpha }\end{array}$ & GADD45A & 1647 & Hs00169255_m1 & $\begin{array}{l}\text { Involved in neuromuscular junction } \\
\text { denervation }\end{array}$ \\
\hline Histone deacetylase 4 & HDAC4 & 9759 & Hs01041638_m1 & Involved in bone development \\
\hline Hypoxia Inducible Factor 1, Alpha Subunit & HIF1A & 3091 & Hs00153153_m1 & Involved in glucose metabolism \\
\hline Insulin-Like Growth Factor 1 & IGF1 & 3479 & Hs01547656_m1 & Growth promoting \\
\hline
\end{tabular}




\begin{tabular}{|c|c|c|c|c|}
\hline Interferon, Gamma & IFNG & 3458 & Hs00989291_m1 & $\begin{array}{l}\text { Involved in the regulation of immune } \\
\text { and inflammatory response, promotes } \\
\text { Th1 differentiation }\end{array}$ \\
\hline Interleukin 1 Receptor Antagonist & IL1RN & 3557 & Hs00893626_m1 & $\begin{array}{l}\text { Inhibits the activities of IL1A/IL1B, and } \\
\text { modulates a variety of interleukin } 1 \\
\text { related immune and inflammatory } \\
\text { responses }\end{array}$ \\
\hline Interleukin 1, Beta & IL1B & 3553 & Hs00174097_m1 & $\begin{array}{l}\text { Proliferation and maturation of } \\
\text { lymphocytes, involved in inflammation } \\
\text { and acute-phase response }\end{array}$ \\
\hline Interleukin 10 & IL10 & 3586 & Hs00961622_m1 & $\begin{array}{l}\text { Down-regulates the expression of Th1 } \\
\text { cytokines, enhances B cell survival, } \\
\text { proliferation, and antibody production, } \\
\text { able to block NF- } \mathrm{kB} \text { activity }\end{array}$ \\
\hline Interleukin 12 & IL12 & 3592 & Hs01073447_m1 & $\begin{array}{l}\text { Involved in the differentiation of naive } \mathrm{T} \\
\text { cells into Th1 cells. Able to stimulates } \\
\text { INFG and TNF } \alpha\end{array}$ \\
\hline Interleukin 13 & IL13 & 3596 & Hs00174379_m1 & $\begin{array}{l}\text { Anti-inflammatory properties, closely } \\
\text { related to IL4 }\end{array}$ \\
\hline Interleukin 15 & IL15 & 3600 & Hs01003716_m1 & $\begin{array}{l}\text { Regulates } \mathrm{T} \text { and natural killer cell } \\
\text { activation and proliferation }\end{array}$ \\
\hline Interleukin 17A & IL17A & 3605 & Hs00174383_m1 & $\begin{array}{l}\text { Pro-inflammatory cytokine, that may } \\
\text { stimulate the expression of IL6 }\end{array}$ \\
\hline Interleukin 18 & IL18 & 3606 & Hs01038788_m1 & $\begin{array}{l}\text { Involved in bone formation and } \\
\text { inflammation }\end{array}$ \\
\hline Interleukin 2 & IL2 & 3558 & Hs00174114_m1 & $\begin{array}{l}\text { Involved in differentiation, immune } \\
\text { responses and homeostasis }\end{array}$ \\
\hline Interleukin $23 \mathrm{~A}$ & IL23A & 51561 & Hs00900828_g1 & $\begin{array}{l}\text { Involved in inflammation, increases } \\
\text { angiogenesis }\end{array}$ \\
\hline Interleukin 6 & IL6 & 3569 & Hs00985639_m1 & $\begin{array}{l}\text { A pleiotropic cytokine that plays } \\
\text { important roles in the acute-phase } \\
\text { response inflammation }\end{array}$ \\
\hline
\end{tabular}




\begin{tabular}{|c|c|c|c|c|}
\hline Myocyte-specific enhancer factor $2 \mathrm{C}$ & MEF2C & 4208 & |Hs00231149_m1 & Involved in bone development \\
\hline $\begin{array}{l}\text { Nuclear Receptor Subfamily 4, Group A, } \\
\text { Member } 2\end{array}$ & NR4A2 & 4929 & Hs00428691_m1 & $\begin{array}{l}\text { Transcription factor, involved in energy } \\
\text { metabolism and inflammation }\end{array}$ \\
\hline $\begin{array}{l}\text { Nuclear Receptor Subfamily, Group H, } \\
\text { Member } 3\end{array}$ & NR1H3 & 10062 & Hs00172885_m1 & $\begin{array}{l}\text { Transcription factor, involved in lipid } \\
\text { metabolism and inflammation }\end{array}$ \\
\hline $\begin{array}{l}\text { Peroxisome Proliferator-Activated Receptor } \\
\text { Gamma, Coactivator } 1 \text { Alpha }\end{array}$ & PPARGC1A & 10891 & Hs01016719_m1 & $\begin{array}{l}\text { Involved in energy metabolism and } \\
\text { inflammation }\end{array}$ \\
\hline $\begin{array}{l}\text { Peroxisome Proliferator-Activated Receptor } \\
\text { Gamma, Coactivator } 1 \text { Beta }\end{array}$ & PPARGC1B & 133522 & Hs00991676_m1 & $\begin{array}{l}\text { Involved in energy metabolism and } \\
\text { inflammation }\end{array}$ \\
\hline Pyruvate Dehydrogenase Kinase, Isozyme 4 & PDK4 & 5166 & Hs01037712_m1 & Involved in glucose metabolism \\
\hline Runt-Related Transcription Factor 1 & RUNX1 & 861 & Hs01021971_m1 & $\begin{array}{l}\text { Involved in neuromuscular junction } \\
\text { denervation }\end{array}$ \\
\hline Runt-related transcription factor 2 & RUNX2 & 860 & Hs01047973_m1 & Involved in bone development \\
\hline Sirtuin 1 & SIRT1 & 23411 & Hs01009006_m1 & Involved in energy metabolism \\
\hline Stearoyl-CoA Desaturase & SCD & 6319 & Hs01682761_m1 & Involved in fat metabolism \\
\hline Superoxide Dismutase 1, Soluble & SOD1 & 6647 & Hs00533490_m1 & $\begin{array}{l}\text { Involved in the anti-oxidative defense } \\
\text { destroying free superoxide radicals in the } \\
\text { body }\end{array}$ \\
\hline TATA Box Binding Protein & TBP & 6908 & Hs00427620_m1 & $\begin{array}{l}\text { General transcription factor that } \\
\text { functions at the core of the DNA-binding } \\
\text { multiprotein factor TFIID (used as } \\
\text { housekeeping gene) }\end{array}$ \\
\hline Toll-like Receptor 2 & TLR2 & 7097 & Hs01872448_s1 & $\begin{array}{l}\text { Involved in recognition of pathogen- } \\
\text { associated molecular patterns, mediate } \\
\text { the production of cytokines necessary for } \\
\text { the development of effective immunity }\end{array}$ \\
\hline Toll-like Receptor 4 & TLR4 & 7099 & Hs00152939_m1 & $\begin{array}{l}\text { Involved in recognition of pathogen- } \\
\text { associated molecular patterns, mediate } \\
\text { the production of cytokines necessary for } \\
\text { the development of effective immunity }\end{array}$ \\
\hline
\end{tabular}




\begin{tabular}{|l|l|l|l|l|} 
& & & & \\
Tumor Necrosis Factor, alpha & TNFA & 7124 & Hs01113624_g1 & $\begin{array}{l}\text { Protypical pro-inflammatory cytokine, } \\
\text { immune system development and } \\
\text { apoptosis }\end{array}$ \\
\hline $\begin{array}{l}\text { Tumor Necrosis Factor Ligand Superfamily } \\
\text { Member 11 }\end{array}$ & TNFSF11 & 8600 & Hs00243522_m1 & $\begin{array}{l}\text { Involved in osteoclast differentiation and } \\
\text { activation }\end{array}$ \\
\hline $\begin{array}{l}\text { Tumor Necrosis Factor Receptor Superfamily, } \\
\text { Member 11A, NFKB activator }\end{array}$ & TNFRSF11A & 8792 & Hs00921372_m1 & $\begin{array}{l}\text { Involved in osteoclast differentiation and } \\
\text { activation }\end{array}$ \\
\hline $\begin{array}{l}\text { Tumor Necrosis Factor Receptor Superfamily, } \\
\text { Member 11B }\end{array}$ & TNFRSF11B & 4982 & Hs00900358_m1 & Involved in bone development \\
\hline $\begin{array}{l}\text { Tumor Necrosis Factor Receptor Superfamily, } \\
\text { Member 1A }\end{array}$ & TNFRSF1A & 7132 & Hs01042313_m1 & Involved in TNF-signaling \\
\hline $\begin{array}{l}\text { Tumor Necrosis Factor Receptor Superfamily, } \\
\text { Member 1B }\end{array}$ & TNFRSF1B & 7133 & Hs00153550_m1 & Involved in TNF-signaling \\
\hline Uncoupling Protein 2 & UCP2 & 7351 & Hs01075227_m1 & $\begin{array}{l}\text { Involved in energy metabolism, } \\
\text { oxidation }\end{array}$ \\
\hline $\begin{array}{l}\text { Vitamin D (1,25-dihydroxyvitamin D3) } \\
\text { receptor }\end{array}$ & VDR & 7421 & Hs00172113_m1 & Involved in vitamin D metabolism \\
\hline
\end{tabular}


Table S2. Median values from mRNA analysis in PBMCs calculated as $2^{-\Delta \mathrm{Ct}}$ at baseline and at the end of the intervention in subjects consuming a low-fat, protein-enriched milk (protein group). The mRNA expression was analysed by quantitative real-time RT-PCR and normilized to the endogenous control genes $T B P$ and $B 2 M$. The p-values indicate changes between end of study and baseline values. The $n$ equals the number of mRNA samples for each gene.

\begin{tabular}{|c|c|c|c|c|}
\hline Gene & Timepoint & n & $\begin{array}{l}2^{-\Delta \mathrm{Ct}} \text { value } \\
\text { (median) }\end{array}$ & p-value \\
\hline \multirow{2}{*}{ CCL2 } & Baseline & \multirow{2}{*}{12} & 0.0014 & \multirow{2}{*}{0.29} \\
\hline & End & & 0.0017 & \\
\hline \multirow{2}{*}{ CHI3L1 } & Baseline & \multirow{2}{*}{14} & 0.0006 & \multirow{2}{*}{0.58} \\
\hline & End & & 0.0007 & \\
\hline \multirow{2}{*}{ CXCL16 } & Baseline & \multirow{2}{*}{12} & 0.0599 & \multirow{2}{*}{0.25} \\
\hline & End & & 0.0618 & \\
\hline \multirow{2}{*}{ DPP4 } & Baseline & \multirow{2}{*}{14} & 0.0704 & \multirow{2}{*}{0.74} \\
\hline & End & & 0.0677 & \\
\hline \multirow{2}{*}{ FAS } & Baseline & \multirow{2}{*}{14} & 0.0774 & \multirow{2}{*}{0.65} \\
\hline & End & & 0.0717 & \\
\hline \multirow{2}{*}{ FBX } & Baseline & \multirow{2}{*}{14} & 0.0798 & \multirow{2}{*}{0.74} \\
\hline & End & & 0.0766 & \\
\hline \multirow{2}{*}{ FOXO1 } & Baseline & \multirow{2}{*}{14} & 0.0654 & \multirow{2}{*}{0.73} \\
\hline & End & & 0.0626 & \\
\hline \multirow{2}{*}{ GADD45A } & Baseline & \multirow{2}{*}{14} & 0.0069 & \multirow{2}{*}{0.25} \\
\hline & End & & 0.0068 & \\
\hline \multirow{2}{*}{ HDAC4 } & Baseline & \multirow{2}{*}{11} & 0.0534 & \multirow{2}{*}{0.85} \\
\hline & End & & 0.0577 & \\
\hline \multirow{2}{*}{ HIF1A } & Baseline & \multirow{2}{*}{14} & 0.2395 & 006 \\
\hline & End & & 0.2261 & 0.90 \\
\hline & Baseline & 11 & 0.0141 & P 12 \\
\hline $\mathrm{IFNG}$ & End & 14 & 0.0140 & 0.12 \\
\hline ICF1 & Baseline & & 0.0002 & \\
\hline IGFI & End & 13 & 0.0001 & 0.25 \\
\hline UI 10 & Baseline & 13 & 0.0005 & 80 \\
\hline ILI0 & End & 13 & 0.0005 & 0.89 \\
\hline II $12 \mathrm{~A}$ & Baseline & 13 & 0.0103 & 072 \\
\hline & End & & 0.0103 & \\
\hline U 15 & Baseline & 12 & 0.0119 & 061 \\
\hline IL15 & End & 13 & 0.0110 & 0.01 \\
\hline II 18 & Baseline & 11 & 0.0030 & 018 \\
\hline 1218 & End & 11 & 0.0032 & 0.18 \\
\hline II $1 \mathrm{P}$ & Baseline & 14 & 0.0204 & 058 \\
\hline ILIB & End & 14 & 0.0174 & 0.58 \\
\hline
\end{tabular}




\begin{tabular}{|c|c|c|c|c|}
\hline \multirow{2}{*}{ IL1RN } & \multirow{2}{*}{\begin{tabular}{|l} 
Baseline \\
End \\
\end{tabular}} & \multirow{2}{*}{14} & 0.0559 & \multirow{2}{*}{0.83} \\
\hline & & & 0.0557 & \\
\hline \multirow{2}{*}{ IL23A } & Baseline & \multirow{2}{*}{14} & 0.0130 & \multirow{2}{*}{0.45} \\
\hline & End & & 0.0155 & \\
\hline \multirow{2}{*}{ IL2 } & Baseline & \multirow{2}{*}{14} & 0.0004 & \multirow{2}{*}{0.93} \\
\hline & End & & 0.0003 & \\
\hline \multirow{2}{*}{ IL6 } & Baseline & \multirow{2}{*}{14} & 0.0010 & \multirow{2}{*}{0.63} \\
\hline & End & & 0.0011 & \\
\hline \multirow{2}{*}{ MEF2C } & Baseline & \multirow{2}{*}{13} & 0.1033 & \multirow{2}{*}{0.14} \\
\hline & End & & 0.1061 & \\
\hline \multirow{2}{*}{ NR1H3 } & Baseline & \multirow{2}{*}{14} & 0.0098 & \multirow{2}{*}{0.06} \\
\hline & End & & 0.0100 & \\
\hline \multirow{2}{*}{ NR4A2 } & Baseline & \multirow{2}{*}{14} & 0.0018 & \multirow{2}{*}{0.81} \\
\hline & End & & 0.0016 & \\
\hline \multirow{2}{*}{ PDK4 } & Baseline & \multirow{2}{*}{14} & 0.0597 & 021 \\
\hline & End & & 0.0496 & 0.24 \\
\hline PPARGC1A & Baseline & 13 & 0.0018 & 015 \\
\hline PPAKULIA & End & 13 & 0.0011 & 0.15 \\
\hline & Baseline & 14 & 0.0165 & 063 \\
\hline PPAKGLIB & End & 14 & 0.0172 & 0.05 \\
\hline RIINX1 & Baseline & 14 & 0.0971 & 080 \\
\hline KUNXI & End & 14 & 0.0968 & 0.00 \\
\hline RIINX? & Baseline & 14 & 0.0832 & 083 \\
\hline KUNX 2 & End & 14 & 0.0790 & 0.85 \\
\hline SCD & Baseline & 14 & 0.0086 & 080 \\
\hline $\mathrm{SCD}$ & End & 14 & 0.0090 & 0.80 \\
\hline SIRT1 & Baseline & 14 & 0.0452 & 076 \\
\hline SIK 11 & End & 14 & 0.0448 & 0.10 \\
\hline SOD1 & Baseline & 14 & 0.2823 & 010 \\
\hline SUDI & End & 14 & 0.2232 & 0.19 \\
\hline TI R? & Baseline & 14 & 0.0504 & 020 \\
\hline ILRZ & End & 14 & 0.0455 & 0.20 \\
\hline TI R 4 & Baseline & 14 & 0.0580 & 088 \\
\hline 1LK4 & End & 14 & 0.0531 & 0.00 \\
\hline TNFr & Baseline & 14 & 0.0478 & \\
\hline $\operatorname{lN} \Gamma \alpha$ & End & 14 & 0.0471 & 0.71 \\
\hline TNER SF11A & Baseline & 13 & 0.0030 & 030 \\
\hline INFKNFIIA & End & 13 & 0.0032 & 0.39 \\
\hline TNER SF1A & Baseline & 14 & 0.0791 & 076 \\
\hline IVEKSTIA & End & 14 & 0.0884 & 0.10 \\
\hline TNFRSF1B & Baseline & 14 & 0.2635 & \\
\hline ПNTKSTID & End & 14 & 0.3494 & 0.63 \\
\hline TNFSF11 & Baseline & 13 & 0.0019 & 029 \\
\hline INFSFII & End & 13 & 0.0015 & 0.29 \\
\hline $\mathrm{UCP} 2$ & Baseline & 14 & 1.7140 & 0.49 \\
\hline
\end{tabular}




\begin{tabular}{|l|l|l|l|l|} 
& End & & 2.0163 & \\
\hline \multirow{2}{*}{ VDR } & Baseline & \multirow{2}{*}{7} & 0.0093 & \multirow{2}{*}{0.41} \\
\cline { 2 - 2 } & End & & 0.0080 & \\
\hline
\end{tabular}


Table S3. Median values from mRNA analysis in PBMCs calculated as $2^{-\Delta \mathrm{Ct}}$ at baseline and at the end of the intervention in subjects consuming an isocaloric control drink consisting of carbohydrate only. The mRNA expression were analysed using quantitative real-time RTPCR and normilized to the endogenous control genes TBP and $B 2 M$. The p-values are indicating changes between end of study and baseline values. The $n$ equals the number of mRNA samples for each gene.

\begin{tabular}{|c|c|c|c|c|}
\hline Gene & Timepoint & $\mathbf{n}$ & $\begin{array}{c}2^{-\Delta \mathrm{Ct}} \text { value } \\
\text { (median) }\end{array}$ & p-value \\
\hline \multirow{2}{*}{ CCL2 } & Baseline & \multirow{2}{*}{16} & 0.0017 & \multirow{2}{*}{0.34} \\
\hline & End & & 0.0018 & \\
\hline \multirow{2}{*}{ CHI3L1 } & Baseline & \multirow{2}{*}{16} & 0.0006 & \multirow{2}{*}{0.96} \\
\hline & End & & 0.0008 & \\
\hline \multirow{2}{*}{ CXCL16 } & Baseline & \multirow{2}{*}{15} & 0.0692 & \multirow{2}{*}{0.81} \\
\hline & End & & 0.0728 & \\
\hline \multirow{2}{*}{ DPP4 } & Baseline & \multirow{2}{*}{17} & 0.0588 & \multirow{2}{*}{0.01} \\
\hline & End & & 0.0819 & \\
\hline \multirow{2}{*}{ FAS } & Baseline & \multirow{2}{*}{17} & 0.0745 & \multirow{2}{*}{0.34} \\
\hline & End & & 0.0685 & \\
\hline \multirow{2}{*}{ FBX } & Baseline & \multirow{2}{*}{17} & 0.0741 & \multirow{2}{*}{0.17} \\
\hline & End & & 0.0787 & \\
\hline \multirow{2}{*}{ FOXO1 } & Baseline & \multirow{2}{*}{16} & 0.0672 & \multirow{2}{*}{0.38} \\
\hline & End & & 0.0690 & \\
\hline \multirow{2}{*}{ GADD45A } & Baseline & \multirow{2}{*}{17} & 0.0064 & \multirow{2}{*}{0.27} \\
\hline & End & & 0.0062 & \\
\hline \multirow{2}{*}{ HDAC4 } & Baseline & \multirow{2}{*}{17} & 0.0601 & \multirow{2}{*}{0.76} \\
\hline & End & & 0.0573 & \\
\hline \multirow{2}{*}{ HIF1A } & Baseline & \multirow{2}{*}{17} & 0.2549 & \\
\hline & End & & 0.2283 & 0.38 \\
\hline IFNG & Baseline & 16 & 0.0107 & 007 \\
\hline IFIVU & End & 10 & 0.0080 & 0.01 \\
\hline IGF1 & Baseline & 16 & 0.0002 & 085 \\
\hline 10Г1 & End & 10 & 0.0002 & 0.03 \\
\hline UI 10 & Baseline & 15 & 0.0004 & 020 \\
\hline IL10 & End & 12 & 0.0003 & 0.29 \\
\hline II $12 \mathrm{~A}$ & Baseline & 17 & 0.0101 & 098 \\
\hline ILI $\angle A$ & End & 17 & 0.0091 & 0.98 \\
\hline U 15 & Baseline & 17 & 0.0131 & $\Omega \cap 0$ \\
\hline ILIS & End & 11 & 0.0105 & 0.09 \\
\hline II 18 & Baseline & 16 & 0.0034 & 064 \\
\hline 1210 & End & & 0.0035 & \\
\hline $\mathrm{II} 1 \mathrm{R}$ & Baseline & & 0.0209 & 19 \\
\hline ILIB & End & 17 & 0.0171 & 0.19 \\
\hline
\end{tabular}




\begin{tabular}{|c|c|c|c|c|}
\hline \multirow{2}{*}{ IL1RN } & Baseline & \multirow{2}{*}{17} & 0.0601 & \multirow{2}{*}{0.34} \\
\hline & End & & 0.0589 & \\
\hline \multirow{2}{*}{ IL23A } & Baseline & \multirow{2}{*}{17} & 0.0117 & \multirow{2}{*}{0.31} \\
\hline & End & & 0.0142 & \\
\hline \multirow{2}{*}{ IL2 } & Baseline & \multirow{2}{*}{17} & 0.0004 & \multirow{2}{*}{0.79} \\
\hline & End & & 0.0004 & \\
\hline \multirow{2}{*}{ IL6 } & Baseline & \multirow{2}{*}{17} & 0.0011 & \multirow{2}{*}{0.08} \\
\hline & End & & 0.0010 & \\
\hline \multirow{2}{*}{ MEF2C } & Baseline & \multirow{2}{*}{15} & 0.1073 & \multirow{2}{*}{0.90} \\
\hline & End & & 0.1072 & \\
\hline \multirow{2}{*}{ NR1H3 } & Baseline & \multirow{2}{*}{17} & 0.0089 & \multirow{2}{*}{0.18} \\
\hline & End & & 0.0085 & \\
\hline \multirow{2}{*}{ NR4A2 } & Baseline & \multirow{2}{*}{17} & 0.0022 & \multirow{2}{*}{0.62} \\
\hline & End & & 0.0017 & \\
\hline \multirow{2}{*}{ PDK4 } & Baseline & \multirow{2}{*}{17} & 0.0659 & \multirow{2}{*}{0.06} \\
\hline & End & & 0.0550 & \\
\hline PPARGC1A & Baseline & 15 & 0.0016 & 055 \\
\hline FFAKUCIA & End & 12 & 0.0008 & 0.55 \\
\hline & Baseline & & 0.0186 & 026 \\
\hline PPAKGLIB & End & $1 /$ & 0.0158 & 0.20 \\
\hline RINX1 & Baseline & 17 & 0.0932 & 048 \\
\hline KUNXI & End & 17 & 0.0999 & 0.48 \\
\hline RIINX? & Baseline & 17 & 0.0778 & 041 \\
\hline KUNX 2 & End & 17 & 0.0816 & 0.41 \\
\hline SCD & Baseline & & 0.0079 & 008 \\
\hline $\operatorname{sen}$ & End & 10 & 0.0075 & 0.08 \\
\hline SIRT1 & Baseline & 17 & 0.0505 & 021 \\
\hline SIK 11 & End & 17 & 0.0456 & 0.21 \\
\hline SOD1 & Baseline & 17 & 0.2248 & 087 \\
\hline SUDI & End & $1 /$ & 0.2127 & 0.81 \\
\hline TI P? & Baseline & & 0.0487 & 000 \\
\hline ILR2 & End & 10 & 0.0468 & 0.99 \\
\hline TI R4 & Baseline & 16 & 0.0666 & 094 \\
\hline $1 \mathrm{LK} 4$ & End & 10 & 0.0667 & 0.94 \\
\hline TNF $\alpha$ & Baseline & 17 & 0.0445 & \\
\hline INF & End & 17 & 0.0443 & 0.96 \\
\hline TNER SF11A & Baseline & 14 & 0.0038 & 004 \\
\hline TNFRSFIIA & End & 14 & 0.0034 & 0.94 \\
\hline TNFR SF1A & Baseline & 17 & 0.0675 & 003 \\
\hline INГKSГIA & End & 11 & 0.0685 & 0.03 \\
\hline & Baseline & 15 & 0.3333 & \\
\hline INFKSFIB & End & 15 & 0.3595 & 0.34 \\
\hline TNFCF11 & Baseline & 16 & 0.0017 & 025 \\
\hline ANFSFI & End & 10 & 0.0021 & 0.25 \\
\hline $\mathrm{UCP} 2$ & Baseline & 15 & 2.1228 & 0.76 \\
\hline
\end{tabular}




\begin{tabular}{|c|c|c|c|c|}
\hline & End & & 1.8480 & \\
\hline \multirow{2}{*}{ VDR } & Baseline & \multirow{2}{*}{6} & 0.0097 & \multirow{2}{*}{0.25} \\
\hline & End & & 0.0093 & \\
\hline
\end{tabular}


Table S4. Distribution of lymphocytes and monocytes, expressed as percent, in PMBCs in subjects receiving protein-enriched drinks $(n=14)$ or control $(n=17)$. The $p$-values indicate changes between baseline values and end of study.

\begin{tabular}{|c|c|l|c|c|c|c|}
\hline \multirow{2}{*}{ Drink } & \multirow{2}{*}{ Cell type } & & \multicolumn{3}{|c|}{ Percentiles } & \multirow{2}{*}{ p-value } \\
\cline { 3 - 6 } & & & $\mathbf{2 5}$ & $\mathbf{5 0}$ & $\mathbf{7 5}$ & \\
\hline \multirow{3}{*}{$\begin{array}{c}\text { Protein } \\
(\mathrm{n}=14)\end{array}$} & \multirow{2}{*}{ Lymphocytes } & Baseline & 14.4 & 16.1 & 19.7 & \multirow{2}{*}{0.78} \\
\cline { 3 - 6 } & Monocytes & End & 14.7 & 15.8 & 18.2 & \\
\cline { 3 - 6 } & Baseline & 3.6 & 4.3 & 4.9 & \multirow{2}{*}{0.93} \\
\cline { 3 - 6 } & End & 3.5 & 4.4 & 5.0 & \\
\hline \multirow{3}{*}{$\begin{array}{c}\text { Control } \\
(\mathrm{n}=17)\end{array}$} & Lymphocytes & Baseline & 13.9 & 17.5 & 19.3 & \multirow{2}{*}{0.92} \\
\cline { 3 - 6 } & Mnd & 14.1 & 16.1 & 19.0 & \\
\cline { 3 - 6 } & Monocytes & Baseline & 3.8 & 4.2 & 4.7 & \multirow{2}{*}{0.10} \\
\cline { 3 - 6 } & End & 4.1 & 4.0 & 5.2 & \\
\hline
\end{tabular}

